\title{
REVOLUȚIA CULTURALĂ DIN OCCIDENT: MANIFESTĂRI ȘI TENDINȚE
}

\author{
Ion PLĂMĂDEALĂ \\ Institutul de Filologie Română „Bogdan Petriceicu-Hasdeu”, Chișinău
}

Rezumat. Comunicarea descrie sintetic originile, manifestările simptomatice și trăsăturile relevante ale revoluției culturale woke care a cuprins în ultimii ani democrațiile occidentale provocându-le nenumărate mutații și involuții către forme de iliberalism și totalitarism soft de sorginte neomarxistă. Sunt descriși principalii factori de radicalizare şi accelerare ai transformărilor revoluționare, degradarea acestora în tendințe nihiliste de indeterminare și negativitate pură contra oricărei idei de organizare socială ierarhică, este evaluat rolul elitelor cognitive și conducătoare care sacrifică adevărul și libertățile în numele unei dreptăți rasiale și sociale utopice.

Cuvinte-cheie: Revoluție culturală, Woke, intersecționalitate, teoria critică a rasei, totalitarism soft, cenzură.

Abstract. The paper synthetically describes the origins, symptomatic manifestations and relevant features of the woke cultural revolution that has engulfed Western democracies in recent years, causing them countless mutations and involutions to forms of illiberalism and soft totalitarianism. The main factors of radicalization and acceleration of revolutionary transformations are described, and their degradation into nihilistic tendencies of indeterminacy and pure negativity against any idea of hierarchical social order, the role of cognitive and leading elites who sacrifice truth and freedom in the name of a utopian racial and social justice.

Keywords: Cultural Revolution, Woke, Intersectionality, Critical Race Theory, Soft Totalitarianism, Censorship.

În continuare vom încerca să prezentăm cât mai sintetic și succint cu putință câteva trăsături, manifestări și tendinţe paradigmatice pentru fenomenul complex pe care 1-am numit „revoluția culturală din Occident”. Prin acest concept operațional, ne referim la suita de evenimente cruciale și schimbări de natură revoluționară care au marcat tranziţia societăţilor din Vest, începând din anii '60 ai secolului trecut, de la societatea industrială de producție la societatea postindustrială de consum, la lumea postmodernă în care identităţile oamenilor sunt definite primordial nu 
atât prin ceea ce ei produc, cât prin ceea ce consumă, în care culturalul predomină asupra economicului și cultura devine teren de războaie ideologice și politice, iar realitatea e redusă la o lume textualizată și „hiperreală” de „simulări și simulacre” (J. Baudrillard). Respectiv, gândirea postmodernistă conceptualizează această reducție a realității la un produs al socializării și experiențelor trăite în modul în care sunt construite prin limbaj, ea îmbrăţișează deconstrucția și indeterminarea radicală. Mutația profundă a epistemologiei către forme radicale de scepticism și cinism, deconstrucționism și constructivism se produce în anii 1990, când sunt respinse în bloc valorile iluministe, anume credința în cunoașterea obiectivă, adevărul universal, știința ca metodă pentru a obține o cunoaștere fiabilă, puterea rațiunii, natura umană universală și individul autonom.

De altă parte, Europa Centrală și cea de Est nu au trecut prin experiențe istorice similare în plan de civilizație și cultură, ceea ce explică mai multe dezacorduri filosofice apărute după căderea Zidului Berlinului între intelectualii din fostul bloc sovietic și confrații lor din Occident, diversitate care astăzi rezonează în conflictele culturale din interiorul Uniunii Europene. Suportând calvarul vieții sub totalitarismul comunist și trăind pe viu drama deznaționalizării și rusificării, ei au elaborat un discurs disident și critic inclusiv față de pervertirile fundamentaliste ale modernității occidentale, care, în numele emancipării absolute a individului, înfăptuiește cu o fervoare mesianică un vast proiect de dezrădăcinare a populațiilor autohtone europene nu numai de matricea lor etnoculturală națională și creștină, de adevărurile spirituale profunde, dar și de constantele antropologice universale, începând cu dualitatea și asimetria sexuală.

Lucrurile respective au fost amintite aici pentru a preciza că atât în selecția temei pentru această comunicare, cât și a unghiurilor de abordare, ne-am inspirat din gândirea și etosul cunoscuţilor disidenți Aleksandr Soljeniţîn, Jan Patočka, Czesław Miłosz și Milan Kundera.

Privită în plan istoric, revoluția culturală de azi, numită prin termeni precum woke, Intersectionality/ intersecționalitate sau Social Justice/ Dreptate Socială, în multe privințe poate fi considerată drept o încununare a cunoscutelor revolte din anii 50-60 ale tineretului studențesc care, fiind radicalizat de ideologiile libertare și comuniste, a militat masiv contra tuturor formelor de putere și autoritate emanate de la indivizi, instituții, tradiții și norme morale moștenite. Predominau atunci cerințele de autonomie și libertăți neîngrădite pentru noul individ narcisic al societăţii de consum, mașină dezirantă pentru care nu trebuie să existe niciun fel de limite și constrângeri morale în calea împlinirii poftelor și dorințelor sale incitate de industria publicității. Noile mentalităţi, practici și reforme implementate de elitele educate în acea perioadă au instituit un tip de ,contracultură”, care în câteva decenii a devenit o cultură dominantă integrată în dinamica capitalismului planetar, în timp 
ce cultura majoritară anterioară structurată pe matricea iudeo-creștină și grecolatină a trecut într-o fază de minorat și disidență. Preluând, după 1980, puterea instituțională și politică în societățile vestice, așa numita clasă burgheză și boemă descendentă din generația hippie a anilor 60 a uzat de toate pârghiile punitive ale corectitudinii politice pentru a revoluționa în primul rând sentimentul moral, prin transformări rapide ale legislației în legătură cu rasa, sexul, genul, prin alterări ale lexiconului etic și a unor termeni-cheie precum: dreptate, echitate, egalitate, iubire, mariaj ș.a. Toate acestea au denaturat sistemul meritocratic liberal al instituțiilor publice și au dus la un rezultat paradoxal, anume înlocuirea relativismului și permisivității morale revendicate în prima fază cu un puritanism rigid, cu tabuuri și coduri stricte de vorbire și conduită, cu forme totalitare de cenzură și coerciție a celor nonconformiști la noua ortodoxie progresistă.

Pentru a percepe diferențele dintre aceste etape ale revoluției, este instructiv să comparăm sloganurile scandate în anii 60 pe străzile și în universităţile din Paris și New York: „Nici Dumnezeu, nici stăpân!”, „Este interzis de a interzice!”, „Emanciparea omului va fi totală sau nu va fi deloc!”, „Putere imaginației!” (Slogans of 68), „Mai bine roșu decât mort!”, „Faceți dragoste, nu războaie!” (Doyle, 2012, pp. 261;361), cu lozincile și cuvintele de ordine ale militanților actuali: „Ucideți toți bărbații!” (hashtagul Twitter \#KillAllMen), „Femei, eliberați-vă de bărbați, deveniți lesbiene!” (Bouanchaud, 2021), „Un polițist bun este un polițist mort!” (Leclerc, 2020), „Moarte albilor!”, „Femei, voalați-vă!”, „Trăiască mariajul homosexual!” (Sur les murs..., 2018) ș.a.

La fel, pentru a percepe amploarea răsturnărilor survenite, trebuie menționat că revoluția culturală a fost însoțită de alte revoluții care s-au produs în mod silențios după 1980: revoluția geopolitică, revoluția demografică, revoluția economiei financiare, revoluția socială a individualismului și revoluţia digitală. Însumate, ele au produs o basculare antropologică care a transformat raportul cu timpul și spațiul, mentalitățile, credințele și moravurile. Răsturnarea sistemului moral are loc pe fundalul declinului monoteismului iudaic și al celui creștin înlocuite de o religie a umanității politeistă care fagocitează corpusul lor doctrinal și îl reciclează în noi evanghelii sociale. Propovăduite de elitele europene, acestea pun înainte iubirea de celălalt abstract faţă cu iubirea de aproapele concret încurajând în același timp ura de sine, egalează demnitatea umană cu cea animală, nu se mai preocupă de viciile naturii umane, ci de combaterea defectelor sociale precum imperialismul, colonialismul, homofobia, deci virtuțile umanismului creștin sunt înlocuite de ceea ce G.K. Chesterton a numit „virtuţi creștine înnebunite” (Chesterton, 1909, p. 51), un umanitarism nelimitat de vreo antropologie pozitivă.

Ca să înţelegem mai bine originile și velocitatea acestor rupturi și transformări, vom evidenția succint câțiva factori de radicalizare și accelerare. Mai întâi, sursa 
acestor tendințe de ilimitare, de refuz al limitelor și ierarhiilor prestabilite se află în miezul filosofiei liberale, anume disocierea radicală a naturii de cultură, principiul tabula rasa ca o condiție a libertății și autonomiei individuale. De unde, eforturile de a suprima constrângerile morale și instituțiile culturale ce guvernează consumul și apetitul sexual ridicând astfel bariere în calea dinamismului economic. Ulterior, tendințele de inginerie socială și radicalism distructiv au fost agravate de traumele pe care ororile celor două războaie mondiale le-au provocat în psihicul și imaginarul colectiv european, de conștiința vinovată și penitențială a elitelor postbelice care au îmbrățișat cu ardoare paradigma deschiderii și slăbirii complete, cultul diversităţii multiculturaliste, relativismul şi nominalismul cultural și intelectual, ordinea anarhică a liberului-schimb. Se adaugă la acestea negativitatea radicală și indeterminată a contraculturii din anii '60-'70 care încercase să cultive o existență bazată strict pe principiul opoziției ca atare, prin asumarea contradicțiilor și aporiilor, o existență de plutire într-un flux liber de orice linii și ierarhii, într-o derivă textualistă.

Elitele actuale care investesc enorm în multiculturalism și politicile identitare progresiste continuă același joc al opoziției pure și pseudoradicalismului, în speranţa de a-și ispăși culpa omului alb și a-și menține statusul social afișând ostentatoriu viziuni progresiste și stigmatizându-i pe cei din clasele inferioare cu invectiva de „bigot” și „rasist”, pentru că ei se încăpăţânează să persiste în identitate și înrădăcinare. Insist pe această tendință către forme de negativitate indeterminată și opoziție pură, ilustrată antologic de mișcarea din 2011 Occupy Wall Street, pentru că ele caracterizează în mod special perioada revoluționară în care Vestul a intrat după 2010, una ce nu obține finalizare, în care instituțiile sunt sistematic delegitimate, golite de conţinuturile lor politice și culturale originare, în care impulsul revoluționar nu mai este ghidat de ideologii dialectice, precum marxismul, ci de expectații narcisice, de proteste a căror esență este împotriva înseși ideii de organizare socială bazată pe conștiința de sine obiectivă și impersonală, căreia i se substituie singularitatea narcisică, utopia unei comunității construite strict pe legături emoționale de iubire maternă, grijă și recunoaștere dezinteresată (Schwartz, 2016, p. 148-170).

Ca și în arta contemporană care nu-și mai propune să formuleze noi canoane, ci să le distrugă pe cele existente, revoluţia actuală nu se face pentru a funda noi instituții și coduri, ci în scopul contestării codurilor ca atare, a oricărei ordini, o indignare permanentă ridicată la statutul imperativului moral care solicită tinerelor generații să facă tabula rasa, precum acest manifest mediatizat al lui Stéphane Hessel: Indignez-vous! (Hessel, 2010). Astfel se realizează una din premoniţiile lui Fr. Fukuyama din celebra sa lucrare, anume că istoria poate fi condusă de negație mai curând decât de contradicție, că ea poate înainta prin respingerea nihilistă 
a ordinii existente indiferent de alternative sau consecințe: „Experiența ne spune că dacă oamenii nu pot lupta pentru o cauză dreaptă pentru că acea cauză a ieșit învingătoare într-o luptă anterioară, atunci ei vor lupta împotriva acelei cauze juste. Vor lupta, altfel spus, dintr-o anumită plictiseală: pentru că nu-și pot imagina o lume fără luptă. Și dacă cea mai mare parte a lumii în care trăiesc este caracterizată de către democrația pașnică și prosperă, atunci ei vor lupta împotriva acestei păci, a acestei prosperități și împotriva democrației” (Fukuyama, 1994, p. 284).

În fine, vom menționa ultimul și cel mai important factor de radicalizare și accelerare, anume revoluția digitală, explozia rețelelor sociale care au declanșat un tsunami informațional ce zguduie și demolează instituţii, idei, oameni şi guverne. Această formidabilă mașină de negare și dislocare a impulsionat nihilismul și deconstrucția postmodernistă, scepticismul și cinismul generalizat de hermeneuticile suspiciunii acreditând tot mai mult ideea că distrugerea însăși ar fi o formă de progres. Exploatând vulnerabilităţile biologice ale creierului nostru reptilian, ea a difuzat virotic și exponențial panica morală generată de revoluția woke privind injustițiile și opresiunile din SUA și Europa: rasism, discriminare, homofobie, transfobie, islamofobie, grosofobie, able-ism, age-ism -, lista este interminabilă. În ciuda numeroaselor lucrări sociologice și date empirice care dezmint cu desăvârșire respectivul tablou halucinant, rețelele sociale au inculcat rapid aceste emoții morale în sânul elitelor mediatice, cognitive, manageriale și politice care introduc într-un ritm accelerativ reforme societale. Această capacitate a mediei digitale de a detașa emoțiile de realități, de a le transforma hiperactiv și propaga viral prin recablări algoritmice și dezinhibare a pulsiunilor eului nostru arhaic către satisfacerea sentimentelor de invidie, curiozitate și a dorinței sexuale este responsabilă de anumite fenomene de nevroze sau nebunie colectivă care se produc în prezent în revoluţia culturală woke. Este vorba de simptome care scot la iveală iraţionalismul și religiozitatea smintită la care ne-am referit, atestate în răbufnirile ostentatorii de autoflagelare mazochistă la neofiții religiei antirasiste. În punctul culminant al revoluției woke din 2020, pe fundalul decesului negrului George Floyd de pe urma unei intervenții polițienești, s-au înregistrat, alături de vandalizări și demolări de statui și edificii, sesiuni de rugăciuni și genuflexiuni colective, sanctificarea iconografică a martirului Floyd, fețe bisericești și cetățeni albi care spală picioarele protestanţilor negri, angajamentul cotidianului New York Times de a ortografia întotdeauna cuvântul negru cu majusculă, iar alb cu minusculă, administratori universitari care își cedează benevol posturile în favoarea aşa-numitor persoane rasializate sau se înscriu în treninguri de reeducare a prejudecăților, apeluri și inițiative de a decoloniza științele, inclusiv matematicile, fizica și medicina, profesori de studii clasice care cheamă la eradicarea disciplinei lor pentru că lectura textelor clasice ar produce „,albitate” şi „,rasism”, Universitatea 
Princeton care suprimă studiul limbilor greacă și latină de către studenții înscriși la filologia clasică, nenumărate confesiuni făcute de politicieni și celebrități mediatice pentru păcatul de a fi alb, de felul acestui tweet al actriței Rosanna Arquette: „Imi pare rău că m-am născut albă și privilegiată. Aceasta mă dezgustă și eu resimt o nespusă rușine" (Arquette, 2019). S-a creat astfel ceea ce Eric Kaufmann numește „multiculturalism asimetric”, în care minoritățile sunt elogiate și încurajate să se identifice cu grupurile și culturile lor, iar majoritatea anglo-protestantă este denigrată și i se cere să se prosterneze în fața așa-numitelor ,persoane de culoare” pentru a edifica o societate mai dreaptă și progresistă sub aspect rasial (Kaufmann, 2018, p. 451).

Prin urmare, woke, woke-ness sunt eufemisme care desemnează o rapidă schimbare a moralității și ideologiei politice a albilor liberali pe durata ultimului deceniu, în sensul radicalizării identităţii liberale cosmopolite care se conturase în perioada postbelică, identitate caracterizată de empatie pentru minorităţi și desconsiderare față de majorități și care a dus la cunoscuta secesiune a elitelor de clasele medii și populare. Sondaje sociologice recente relevă că albii liberali din SUA sunt singurul grup demografic care manifestă părtinire în favoarea grupului exterior, adică din grupurile examinate doar albii liberali și-au exprimat o preferință pentru alte comunităţi rasiale și etnice în raport cu propria comunitate (Carl, 2019).

Cuvântul englezesc woke din sintagma Woke Revolution poate fi tradus ca trezire, deșteptare; el conotează sensurile cunoscute din vocabularul marxist de dobândire a conștiinței de clasă și de conștientizare a opresiunilor suferite. Istoria americană cunoaște o deșteptare în anii 1960, apoi la începutul anilor 1990, când ravagiile corectitudinii politice au dus la ceea ce Allan Bloom a descris în celebra sa lucrare cu titlul The Closing of American Mind, și ultima, din anul 2014, pe fundalul tulburărilor sociale din Ferguson și care a fost catalizată de revoluția rețelelor sociale la care ne-am referit. Vehiculat de activiștii din organizația neomarxistă Black Lives Matter, termenul woke e lansat ca injoncțiune adresată militanților cauzei antirasiste de a rămâne „vigilenți” față de orice fel de opresiune a negrilor din partea albilor. Ulterior, sensul a fost extins la opresiunea săracilor de cei bogați, a femeilor de către bărbați, a homosexualilor de heterosexuali etc., astfel ideologia woke integrează de-a valma reclamațiile și nenorocirile presupuse ale diferitor minorități oprimați de grupul majoritar în mod discreționar. Acest grup majoritar este compus din albi (în contextul Europei - din popoarele europene autohtone), iar cele mai malefice ființe din rândurile lor sunt bărbații albi, creștini și heterosexuali. Tot așa cum aceștia din urmă cumulează defectele de a fi alb, masculin și hetero, o universitară americană de stânga, K. Crenshaw, născocește în 1989 conceptul de „intersecționalitate”, ideea că persoanele de culoare, grupurile minoritare se confruntă cu o agregare de discriminări, ceea ce le atribuie statutul onorabil de victime, respectiv, ele sunt 
îndemnate să formeze o coaliţie pentru a răsturna sistemele de opresiune. În baza intersecționalității, care preia locul celebrei lozinci „Proletari din toate țările, uniţivă!", o grupare de activiști și profesori universitari elaborează o nouă disciplină academică, așa-numita Teorie critică a rasei, în fond, o doctrină revoluționară neomarxistă care, plecând de la premisa că America este iremediabil rasistă, imorală și coruptă, își propune să pună în cauză temeliile democraţiei liberale, în primul rând principiul universalismului, din care s-au născut drepturile omului și ideea incarnată de figura lui Martin Luther King Jr. după care oamenii trebuie judecați nu după culoarea pielii, ci după conținutul caracterului și comportamentului lor.

Lucrul frapant, în special pentru un intelectual din Est care mai păstrează vie amintirea catehismului marxist-leninist, este că o disciplină academică obscură a devenit într-un timp foarte scurt ideologia directoare pentru practic toate instituțiile americane, începând de la grădinițe și școli primare, mass-media și marile întreprinderi, ea ghidează toate procesele de admitere și promovare în universități, de selecție și finanțare a cercetărilor academice. Această victorie a woke-ismului îi face pe autori să constate că elitele intelectuale, academice, care sunt în majoritatea absolută de orientare stângistă, au reușit să transforme prin revoluția culturală țara întreagă într-un campus universitar (Sullivan, 2018).

Şi ultimul aspect foarte important și care la fel ar trebui să ne preocupe și pe noi, intelectualii din Est, este dimensiunea tot mai pronunțată a totalitarismului pe care le manifestă aceste mișcări revoluţionare. Indiferent că îl numim un totalitarism soft, adică unul care nu recurge la anihilarea fizică a inamicului ideologic, el desfăşoară un arsenal variat de mijloace punitive și intimidante cunoscute azi sub numele de cancel culture, adică o cultură a anulării, a ștergerii. Este vorba de numeroase forme de ostracizări și condamnări la moarte socială a ereticilor de la dreapta credință, hărțuiri în mediul on-line, blocaje și cenzuri ale exprimării publice, concedieri și suprimări de fonduri ș.a. Cei care nu aderă la doctrina woke sau îndrăznesc să-i pună la îndoială postulatele riscă în orice moment să-și vadă distruse întreprinderea, cariera și reputația. Modurile prin care o cohortă uriașă de birocrați, cărora li se achită salarii cu cinci zerouri, impun dogmele DEI (acronim pentru Diversity, Equity, Inclusion) în toate procesele de admitere, evaluare, angajare și finanţare în universități și cercetare au fost descrise drept practici totalitare de coerciție și îndoctrinare. Recent, apar studii care argumentează că atmosfera ce predomină în educaţia superioară este una de Gulag, o ambianță în care „teroarea și frica îi cuprind pe lucrătorii universitari, pe profesori și administrație" (Abu, 2021) în fața studenților violenți și a noilor elite de minorități care dau o lovitură de stat preluând puterea și controlul. Sondajele sociologice vin să coroboreze aceste interpretări, arătând că tot mai mulţi tineri sunt decepționați de democrație și fascinați de ideea socialistă, că 50\% din studenții universităţilor sunt de acord cu izgonirea vorbitorilor 
„controversați” din campus, iar 20\% încuviințează aplicarea violenței împotriva celor care se presupune că vehiculează idei ofensatoare pentru minorităţi (Rampell, 2017), că majoritatea studenților și a profesorilor se autocenzurează (Kaufmann, 2021). Vânătoarea și pedepsirea disidenților și celor irecuperabili pentru noua ortodoxie a deșteptării, precum în scenele suprarealiste surprinse la universitatea Evergreen, în care studenți înarmaţi cu bâte de baseball patrulează campusul, sechestrează profesori și-i supun ritualului umilitor de pocăință publică pentru presupusele privilegii deținute și convingeri greșite; aceeași umilire simbolică a instituțiilor și businessului în faţa militanților, încurajarea delațiunii în redacțiile celor mai importante mijloace de comunicare în masă, instituirea în edituri, studiouri și unele redacții ale revistelor științifice a funcției de „sensitivity reader”, cu menirea de a cenzura și epura acele lucrări care ar putea leza sensibilitățile minorităţilor, rețele sociale care îi încurajează pe copii și adolescenţi să-și denunţe părinții care nu s-au deșteptat postându-le numele și fotografiile, punerea la index și, mai recent, autodafeul cărților în Canada, precum și alte practici totalitare i-au îndreptățit pe unii cercetători să depisteze numeroase similitudini între revoluția actuală și revoluția culturală chineză. Bineînțeles că ele reproduc mai multe scenarii aplicate iniţial în revoluția culturală sovietică.

În încheiere, dată fiind amploarea acestor procese este riscant să emiți previziuni, totuși observându-le în perspectivă istorică, luând în calcul și viteza cu care ele se propagă, prin eforturile concertate ale giganților media, din lumea anglosaxonă în restul țărilor europene, faptul că aceste religii seculare sunt animate și propulsate de generația milenială și generația Z, care înlocuiesc elitele conducătoare ale celor mai avansate puteri globale, putem prognoza cu certitudine că flagelul woke va bântui Occidentul încă mult timp înainte și că în curând vom ajunge să trăim cu toții într-un campus universitar.

\section{Referințe bibliografice:}

1. ABU, O.L. Georgetown's Cultural Revolution. [on-line] Disponibil: https://quillette. com/2021/04/09/georgetowns-cultural-revolution/ [citat 6.10.2021].

2. ARQUETTE, R. [@RoArquette]. (2019, 7 August). I'm sorry I was born white and privileged. It disgusts me. And I feel so much shame. [Tweet]. Twitter. https://twitter.com/ roarquette/status/1159152878440701952?lang=en

3.BOUANCHAUD,Cecile.La«joie» etle«soulagement»desféministesquise «découvrent» lesbiennes. [on-line]. Diponibil: https://www.lemonde.fr/societe/article/2021/04/25/la-joieet-le-soulagement-des-feministes-qui-se-decouvrent-lesbiennes_6077968_3224.html [citat 21.08.2021].

4. CARL, J. White Liberals and the Cult of Ethnic Sado-Narcissism. [on-line] Disponibil: 
https://amgreatness.com/2019/03/31/white-liberals-and-the-cult-of-ethnic-sado-narcissism [citat 9.10.2021].

5. CHESTERTON G.K. Orthodoxy. London: John Lane Company, 1909.

6. DOYLE, Ch. C, and all. The Dictionary of Modern Proverbs. New Haven and London: Yale University Press, 2012.

7. FUKUYAMA, Fr. Sfârşitul istoriei și ultimul om. București: Paideia, 1994.

8. G.K. Chesterton, G.K. Orthodoxy. London: John Lane Company, 1909.

9. HESSEL, St. Indignez vous! Montpellier: Indigène éditions, 2010.

10. KAUFMANN, E. Academic Freedom in Crisis: Punishment, Political Discrimination, and Self-Censorship, March 1, 2021. [on-line] Disponibil: https://cspicenter.org/reports/ academicfreedom/ [citat: 15.08.2021].

11. KAUFMANN, E. Whiteshift. Populism, Immigration and the Future of White Majorities. London: Penguin, 2018.

12. LECLER, J.-M. Menaces, insultes nominatives et agressions au quotidien. In: Le Figaro. 2020, 16 novembre, p. 4.

13. RAMPELL, C. A chilling study shows how hostile college students are toward free speech. [on-line] Disponibil: https://www.washingtonpost.com/opinions/a-chilling-studyshows-how-hostile-college-students-are-toward-free-speech/2017/09/18/cbb1a234-9ca8-11e 79083-fbfddf6804c2_story.html [citat: 11.07.2021].

14. SCHWARTZ, H.S. Political Correctness and the Destruction of Social Order. London: Palgrave Macmillan, 2016.

15. Slogans of 68. [on-line] Disponibil: https://libcom.org/history/slogans-68 [citat 14.07.2021].

16. SUllivaN, A. We All Live on Campus Now. [on-line] Disponibil: https://nymag. com/intelligencer/2018/02/we-all-live-on-campus-now.html [citat: 7.09.2020].

17. Sur les murs de la Fac de Saint-Denis : «Mort aux Blancs», «Kill cops», «AntiFrance vaincra»... [on-line] Disponibil: https://resistancerepublicaine.com/2018/03/23/sur-les-mursde-la-fac-de-saint-denis-mort-aux-blancs-kill-cops-antifrance-vaincra/ [citat 4.09.2021].

Notă: Articolul a fost realizat în cadrul proiectului de cercetare 20.80009.1606.03 Contexte socioculturale autohtone şi interconexiuni europene în creaţia populară şi literatura cultă din Basarabia (sec. XIX până în prezent), Institutul de Filologie Română «B. P.-Hasdeu” al MEC. 